\title{
CONFLICT BETWEEN CUSTOMARY AND NON-CUSTOMARY SYSTEMS OF LAW : PRELIMINARY OBSERVATIONS
}

\section{Oluwole Agbede}

The co-existence in Nigeria of customary ${ }^{1}$ and imported (English) laws has produced choice of law problems of a nature quite distinct from those for which rules of private international law have been formulated. For, while the latter is concerned with choosing between territorially-based systems of law, the former is concerned with choosing between systems of law that:

"apply concurrently ... without spatial separation within a single territorial jurisdiction ${ }^{2}$."

Until lately, these problems have received little attention not only in Nigeria but also in other parts of common law Africa. The only early work known to this writer on this issue (in territories under British influence) is the work by Goadby ${ }^{3}$ published in 1926 in which the author sought to solve internal conflict of law problems with the rules derived from principles of English private international law.

This compares rather poorly with the intensive study undertaken, and the numerous works published, by continental jurists on this subject ${ }^{4}$.

The reason for the apparent neglect of this vital issue may be found in the judicial set-up in British Colonies. As a result of the existence of a dual system of court problems of internal conflict of law were somewhat concealed. For, a party who intended to seek a remedy under the native law invariably went to the native courts while a party wishing to avail himself of remedies under the "English law" would turn to the "English courts". Although the "English Courts" were empowered by statute to apply native law in certain cases, nevertheless, one gains the impression, from reading the early cases and particularly from the decisions of native courts, that the choice of court nearly always carried with it, the choice of the law to be applied.

There is however a significant change today. Rules of customary law are now frequently applied in the High Courts. Most of these rules are to be found in published works. In Western Nigeria in particular, trained lawyers have, for some time past, been sitting in native courts of higher grades ${ }^{5}$. There are now legislative enactments governing the application of rules of customary law in the various courts $^{6}$. Practically all contemporary writers on Nigerian law have touched on the problem of internal conflict of law.

\footnotetext{
1 The term "Customary Law" include Islamic Law in areas where Islamic law has been customarily adopted.

2 Allott, Essays in African Law, p. 154.

$3 \mathrm{~F}$. M. Goadby, International and Inter-religious Law in Palestine (1926).

4 The following are a few of these jurists and the dates of their publications.

Netherland: Nederburg (1896), André de la Port (1908), Kollenwijn (1929), van den Berg (1912).

Germany: Von Hoffmann (1911), Neumeyer (1912).

France: Dunoyer (1888), Larcher (1908), Armintom (1912), Lamine Gueye (Senegalese) (1922), (Michael) Eliesco (Rumanian) (1925), (Henri) Solus (1927).

5 All Grade A customary courts are now presided over by trained lawyers, and so are most of the Grade B courts.

6 See n. 13 below.
} 
Park, and Keay and Richardson, may be singled out for mentioning for their treatment of this problem in their various works ${ }^{7}$ although their analysis of the issues is hardly more than superficial ${ }^{8}$.

Again, the technique of modelling local statutes on English pattern whereby the rules of local statutes exist side by side with the rules of customary law, has only intensified internal conflict of law problems. The present decade or so has however witnessed various efforts being made to unify the dual system in certain branches of the $\mathrm{law}^{9}$. It is to be hoped that total unification of these laws will only be a matter of time.

From the facts stated above, it may be concluded that internal conflict of laws in Nigeria has an uneventful past, a vigorous present and probably a bleak future.

What is however significant is that there are statutory provisions in the various states which are designed to resolve this conflict ${ }^{10}$. The aim of this essay is to clear some of the fog which has persistently beclouded the basic policy of these enactments and which has produced absurd results in the application and interpretation of this statutory provisions.

It is intended to approach this problem under the headings namely:

Subjection to Customary Law: The principle of resolving conflict of laws on the basis of racial origin of the parties as contained in the various enactments is an illustration of the simplicity which marks the early legislative, enactments and demonstrates the lack of appreciation of the issues involved. How, for example, can the interest or estate in land depend on the nationality of the owner regardless of the nature of the interest he has acquired?

This principle has given rise to a number of misconceptions including the assertion that certain persons are subject to customary law while others are not. The logical by-product of this assertion would be the evolution of segregational or racial laws. Such a development was neither the intention of our legislature nor is it supported by the social fact of Nigerian society where we have witnessed the evolution of a single society shared by all individuals regardless of the race or community to which they belong. All persons in Nigeria are emenable to customary law, the imported (English) law, and to the rules of local statutes in one form or other.

In the words of Dr. Coker:

". . . there is only one system of law, though it is fed by two tributaries, the waters from which have wonderfully mixed ${ }^{11}$."

One must therefore take leave to dismiss as unfounded the deep-rooted assumption shared by contemporary writers that when two non-natives (or Non-Nigerians) enter into a transaction in Nigeria, their respective rights and obligations arising thereof must be governed by non-customary law regardless of their intentions ${ }^{12}$.

Our view is supported by the provisions in all the High Court Laws in Nigeria which state

\footnotetext{
7 Park, Sources of Nigerian Law (1963). Keay and Ridhardson Native and Customary Courts in Nigeria (1966).

8 There are also numerous learned essays on the various aspects of the problem in other jurisdictions in Africa.

9 There is now uniform criminal law all over the country - the Penal Code in the Northern States and the Criminal Code in the Southern States. A conference was held on "Integration of Customary and Modern Legal Systems in Africa" at the University of Ife, Nigeria, in 1964. See Integration of Customary and Modern Legal Systems in Africa (1971) (Edited by The Law Faculty University of Ife) for the conference papers.

10 See n. 13 below.

11 G. B. A. Coker Family Property Among Yorubas (1958) p. 13

12 Park Sources of Nigerian Law. P. 114.
} 
". . . nothing in this Law shall deprive any person of the benefit of any such native law or custom ${ }^{13}$."

By the use of "any person" instead of "any native" or "any Nigerian" it is clear that the legislature guarantees the rights of non-natives to take benefit under the rules of native law.

Furthermore, no mention is made under the relevant provisions as to the applicable law where non-natives enter into a transaction. If it can be deduced from this fact that customary law should not apply, it can equally be deduced, by the same process of reasoning, that non-customary law should not apply. For one thing, no mention is made of its applicability.

Moreover, the mere fact that an act is not expressly permitted does not, by itself, yield the conclusion that it is prohibited. In any case, as there is a provision which directs that customary law be applied in certain cases where natives and non-natives are parties to a transaction, it seems a distortion of facts to assert, as Park has done that there is no provision permitting a non-native to submit himself to customary law. For, not only does the law contemplate such a submission, it actually compels it in certain situation $\mathrm{s}^{14}$.

It seems likely that this view springs from the erroneous assumption that customary law is an exceptional law and as such, its sphere of influence should be confined to transactions between the natives. But as Professor Elias has rightly pointed out:

"Nigerian customary laws are not simply exceptions to the general body of law but are also the 'fons et origo' of a substantial part of the entire law of the country 15 ."

There is no rule of laws in force in Nigeria which prohibits anyone of whatever race or creed from taking benefits or being subjected to liability under this law. Indeed, there are many Nigerian citizens who are, under the relevant statutes prescribing choice of law rules, "non-natives" or "non-Nigerians"16.

But under the Republican constitution, any rule of law which discriminates against any citizen on grounds of race or creed is of no legal force or effect ${ }^{17}$.

Therefore the rule in Savage $v$. Macfoy ${ }^{18}$ that a non-native cannot marry under the customary law on the assumption that "unions involving polygamy are prohibited by English law on grounds of public policy" is not only socially unsound but may also be held unconstitutional under certain circumstances. Our conclusion is that non-natives can validly transact under the customary law.

(ii) Area of Influence of Customary Law: One of the reasons for the introduction of English law into Nigeria was, without doubt, the fact that the rules of customary law were inadequate to cope with the monetary economy and to regulate the large scale peaceful interpenetration of society arising from the establishment of British Administration.

By empowering the British courts to enforce rules of native law and custom in certain cases, it is clear that the British Administrators realised that these rules

\footnotetext{
13 See Sec. 12 (1) H. C. L. Cap. 44 L. W. N. 1959; Sec. 34 (1) H. C. L. Cap. 49 L. N. N. 1963. Sec. 22 (1) H. C. L. Cap. 61 L. E. N. 1963; Sec. 27 (1) H. C. L. A. Cap. 80 L. F. N: L. 1958. 14 See, for example, Sec. 21 (2) H. C. A. (Lagos) Cap. 80 L. F. N. L. 1958.

15 Nigerian Legal System P. 9.

16 A "Nigerian" is defined under the Western State Statute as "a person whose parents are members of any tribes indigenous to Nigeria and the descendants of such persons, and includes any person one of whose parents was a member of such a tribe". See Sec. 2 Customary Court Law Cap. 31. L. W. N. 1959.

17 This provision does not apply to Edict or Decrees as provided by Decree No. 1, 1966.

18 Ronn. 504.
} 
were more suitable to the natives at least in some respects than the introduced law. Consequently, a discussion of internal conflicts of law should necessarily be prefaced by an examination of the areas of influence of customary law.

It seems certain that a failure to appreciate the varying significance of rules of customary law in the various departments of Nigerian law has obscured the views of many judges and some legal writers in their approach to internal conflict of law problems.

One can roughly divide the various departments of law into three categories for this purpose.

(a) Areas in which customary law is silent or expressly abolished.

(b) Areas in which customary law is vague, rudimentary or inadequate.

(c) Areas in which customary law is comparatively fully developed and still dominant.

\section{(a) Area in which customary law is silent or expressly abolished}

One may include under this heading public and private international law, taxation, road traffic, custom and excise, immigration, copyright, banking, insurance, criminal law and punishment and so on.

It is clear that the absence of dualism of law in these spheres avoids problems of choice of law. Therefore to base judicial decisions in these areas on the racial origin of the parties concerned is unhelpful, artificial and rather misleading.

\section{(b) Areas in which customary law is vague, rudimentary or inadequate}

Under this heading, one can justifiably mention the law of tort and contract. Although compensation is often awarded to victims of wrongful acts under the various customary laws (even if the act is brazenly criminal) yet it is not certain whether there is any established general principle of tortious liability under our customary laws as there is under the imported law.

Again, the scale of compensation, which still reflects the rudimentary economy under which customary law of tort has evolved, is so low that a claim against large commercial firms can hardly be based on customary law ${ }^{19}$. It follows therefore that the question whether "English" or customary law is applicable may depend on the nature of the claim rather than on the racial origin of the parties.

A better approach to choice-of-law problems in the field of tort should be based on the choice made by the parties. If the plaintiff chooses to avail himself of remedies under the imported law he surely must take the risk of defences known to that law. Therefore the question whether the Statute of Limitation applies in any cause or matter should not depend on the nationality or racial origin of the parties to the cause or matter but should be determined on whether the claim is based on "English law" and also on whether the statute is applicable in Nigeria

19 In the case of Ewenzekire v. Obanuku (1960) W. N. L. R. 40, for example, the customary court ordered the defendant (in a case of assault) to pay a fine of $£ 1: 10 /$ and to pay compensation of $£ 1: 10 /$ to the victim of his wrongful act. On appeal to the High Court, the plaintiff appellant was awarded $£ 80$ general damages and $£ 7: 2 /$ - special damages. 
or not. But no party should be allowed to seek his remedy under the two systems cumulatively ${ }^{20}$.

There is surely no acceptable reason why the hundreds of petty Syrian traders in Nigeria cannot avail themselves of the cheaper, quicker and less technical adjudication in customary courts in disputes against the (peasant) natives who may not be able to repay even the costs of litigation in the general courts.

One obvious advantage (or disadvantage) of the existence of dual system of law of tort is that this branch of the law is today more comprehensive than the traditional, or the current English law on this subject. For, there are a number of wrongs which are recognised by one or the other system of law only. For example, an action can be based on adultery simpliciter under the customary law but not so under the current English law. One would have thought that any person of whatever race or creed should be able to vindicate his right under any system that recognises such a right. However, by a sort of confused conceptual thinking it has been held that parties to a Christian marriage cannot sue for adultery ${ }^{21}$. It is indeed absurd that the liability of a person who unlawfully interferes with one's spouse should depend, in a single jurisdiction, on the nature of one's marriage ceremony.

On the other hand, the dualism of law in this field is somewhat unsatisfactory. For instance, where a wrongful act is actionable under the two systems the choice of one system as against the other will undoubtedly produce different results. For example, an action for defamation which may attract compensation of hundreds of pounds in the High Court may yield such a paltry sum as five pounds under the Customary law ${ }^{22}$.

It is hardly satisfactory that the extent of a person's liability for a wrongful act should depend on the particular court the issue has been litigated. But a solution to such a problem is beyond the scope of our present discussion.

Law of Contract: Customary law, no doubt, recognises certain kinds of contracts such as sales and pledges of land, sales and bailment of goods, loan of money or articles, apprenticeship of various kinds, co-operative labour contract, contract of agistment, marriage contract and so on. Nevertheless, it is doubtful whether it can be said that there is a general principle of contractual liability under any customary law in Nigeria.

It is often assumed that the dualism of law presents no problem in the field of contract as the court can always ascertain the proper law of the contract ${ }^{23}$. But unless there is a dinstinct third system (that is, a "super law") that prescribes such proper law otherwise it will often be determined in terms of prepossessions imbided from the legal system with which the particular judge is familiar ${ }^{24}$. This writer had personal experience of the complications involved in the problem. The situation can be illustrated as follows. Y, (a native dress-maker) orally agreed to make a wedding dress for $X$ (a native university lecturer) for the sum of $£ 35$.

20 In the East African case of Jessie Nyokebu v. Public Trustee (1965) E. A. 530 (K) it was held by the Court of Appeal (for East African) that where a wrongful act gave rise to compensation under the customary law as well as under the local statute (Fatal Accident Act) the plaintiff must elect between the statutory damages and the customary compensation.

21 Ackah v. Arinta (1893) Sar F. L. R. 78.

22 See n. 18 above.

23 See for example Record of proceedings of the London Conference on "The future of customary Laws in Africa" (London) 1960, p. 41.

24 That is, a judge of the "English court" will ascertain the "proper law" in accordance with the principles of English kaw while a customary court judge will invoke customary law to determine the "proper law". The results are not likely to be the same. 
$\mathrm{X}$ paid a deposit of $£ 10$. Neither of the parties expressed any intention as to the applicable law. $Y$ made the dress a week before the marriage ceremony. Before $X$ go to $Y$ 's place, $Z$ (a native petty trader) offered $Y$ the sum of $£ 40$ for the dress and $Y$ quickly disposed of the dress. On X's arrival, $Y$ expressed regret for his inability to complete the work and refunded the $£ 10$ deposit. By some strange coincidence $X$ eventually bought the particular dress from $Z$ for $£ 45$.

Under the customary law, $\mathrm{Y}$ is probably not liable for X's extra expenses as he has refunded the deposit although he may be obliged to disgorge the gain he has made. Under the imported law he is undoubtedly liable to recoup $\mathrm{X}$ for the additional expenses. But what is the proper law of the contract?

Certainly, $\mathrm{X}$ did not intend that customary law should apply. Y, on his part, knew nothing of English law and could not have intended the application of that law. The proper law thus vanishes into thin air!

Suppose $\mathrm{X}$ has paid no deposit at all. That fact would not have made any difference in the result if "English law" were applicable, but under the customary law $\mathrm{X}$ would probably have no cause of action.

The High court will probably decide this case according to English law ${ }^{25}$ while the customary court will surely apply customary law. We have here the determination of "proper law" yielding so divergent results.

Surely, the need of practical government in modern times calls fo uniformity and certainty in the law regulating economic activities.

\section{(c) Areas in which customary law is comparatively developed and still dominant}

Under this heading, one can mention land law and law relating to personal status - marriage, succession, legitimacy and guardianship.

(i) Land Law: Although conveyance of land in English form is common in the big cities yet the position in Nigeria today is that the vast majority of the people regulate their dealings in land in accordance with the rules of customary law. Indeed, in a society which practices shifting agriculture, the application of English law to farm land is not only inconvenient but undoubtedly unworkable. The attempt of the court to determine the nature of interests in land on the basis of racial origin of the parties have produced absurd consequences. It should be conceded however that it is sound principle to presume that natives normally conclude land transactions under the customary law but this presumption should be rubuttable.

(ii) Law Relating to Personal Status: All societies including the very simple ones, have rules however rudimentary or lax, which regulate the union of man and woman, the procreation of children, succession to property on death and the status of children of various shades of cohabitation. Except for the local Marriage Act which provides for the celebration of monogamous marriages and the consequences arising thereof, all natives of Nigeria are subject to customary law in matters of personal relations.

25 Probably on the pretext that executory contract is unknown to customary law. The culprit in the particular case disappeared before an action could be instituted.

26 See, Opoku, Our Civil Law Neighbours, 4 University of Ghana Law Journal (1967) 40-53; Robert, A. $P$. "Etude conparée des lois applicables et des tribunaux de droit coutumiert dans les territoires français, belges et portugais d'Afrique Noire" Revue juridique et politique d'Outre-Mer (1959) $18-31$. 
Unlike the position in the former French and Belgian territories ${ }^{26}$, for example, there is no means whereby a native of Nigeria can opt out of the domain of customary law Therefore the expression "persons subject to customary law" should mean no more than persons whose personal law is the customary law. It does not mean (and should not mean) that there are persons who are not amenable to customary law. Were it otherwise, the statutory provisions which direct the court to apply customary law "in causes and matters between natives and non-natvies"27 (where injustice would otherwise be caused to either parties) would be incapable of application.

The dominance of customary law in the area of land law and personal relations was given statutory expression in the early enactment which provided for the application of customary law in causes between natives

"particularly, but without derogating from their application in other cases, in causes and matters, relating to marriage and to the tenure and transfer of real and personal property and to inheritance and testamentary disposition ...28."

On the authority of the decided cases $^{29}$ there appears to be no legal means whereby a non-native can have his personal rights determined in the general courts, in accordance with rules of customary law. One however wonders why the "natural justice" 30 clause should not cover such a situation ${ }^{31}$. Nevertheless, if a non-native is subject to the jurisdiction of customary courts, he can take advantage of customary law in all such matters.

\section{Extent of Operation of the Statutory Choice-of-Law Rules:}

It should be borne in mind that the statutory choice-of-law rules under discussion only apply to non-customary courts. Therefore any interpretation placed on these rules does not represent the law in Nigeria as such. It only represents the consequences of litigating in the general courts. Thus when Osborne C. J. held in Savage v. Macfoy that a non-native had no capacity to enter into a customary marriage he was fully aware that he was not stating the law for the customary courts. The Chief Justice made that clear when he said:

". . . no effect will be given in this court (British) whatever view native tribunals may take in such matters, to a polygamous union ${ }^{32}$ ".

The decision in this case hinges on the Chief Justice's understanding of the statutory choice of law rules. As far as the customary court judges are concerned, one can say without any fear of contradiction, that there is no rule of law applicable in their courts which supports this decision. Therefore the conclusion of some authors ${ }^{33}$, based on decided cases, that non-natives cannot contract customary marriages tells half the truth.

\footnotetext{
27 See Sec. 21 (2) H. C. A. (Lagos) Cap. 80 L. F. N. L. 1958.

28 Sec. 14 Supreme Court Ordinance, 1914.

29 See Savage v. Macfoy (supra) and Fonseca v. Passman [1958] W. N. L. R. 41

30 See for example Sec. 34 (4) H. C. L. Cap. 49 L. N. N. 1963.

31 See writer's “Inter-racial Marriage under Nigerian Customary Law”. 1971 N. B. J. 35.

32 Ren. 504.

33 See for example Park op. cit., p. 115.
} 


\section{Purpose of the Statutory Choice of Law Rules:}

In spite of the obvious meaning of these rules, judges and legal writers have elevated them to the pedestal of inflexible rules. Our contention is that the essence of the rules is to guide the courts in reaching a decision. That is, they are merely presumptions. They were never intended to be mechanical slot-machines. This view is supported by the cautious expression contained in all the enactments which provide: "such law and custom shall be deemed applicable . ...34." This surely contemplates the possibility or desirability of applying other laws.

If this view is accepted, then one must dismiss as unfounded, Park's assertion that whatever may be the intention of the parties customary law will not apply where two non-natives enter into transactions in Nigeria. Park hardly realised that he was saying, in effect, that all "non-Nigerians" domiciled in the Western State or all "persons not of Nigerian descent" domiciled in Eastern States, for example, must be governed by "English law" in matters of personal relations and in their dealing inter se. That is, they can only contract "English" or statutory marriages, own land under "English Law", and that succession to their intestate estate will be regulated by "English Law". When it is realised that this category of people includes Yorubas from Dahomey across the border, Cameroonians (who were previously Nigerians), and Hausas from the Chad Republic, the inconvenience and absurdity of this interpretation becomes glaring.

The position therefore appears to be that the courts should presume in favour of the application of non-customary law in such a situation. It will be open to the parties to rebut the presumption by adducing evidence to establish that they intended customary law to apply or that the application of "English Law" will work hardship on them. 
Court in Probate, Divorce and Matrimonial Causes and proceedings shall be exercised in conformity with the law and practice for the time being in force in England. Changes in the law of England automatically affected Ghanaian divorce law.

Ordinance marriage differs from the traditional and Islamic law marriage in basic conceptions and effects. Whilst Ordinance marriage is strictly monogamous, the other forms of marriage are potentially polygamous. The grounds for divorce in English law are limited but traditional law seems to know of no such limitation.

Divorce in English law was based on the principle of fault and the party seeking to dissolve a marriage had to prove that the other party had been guilty of a matrimonial offence. The Matrimonial Causes Act of 1971 has changed the position by making proof of the breakdown of the marriage the sole ground for divorce. Henceforth, it will no longer be the task of the courts to pronounce one party guilty and the other innocent but to find out whether the marriage has broken down beyond all repair.

\section{Conflict between Customary and Non-Customary Systems of Law:}

\section{Preliminary Observations}

\section{By I. Oluwole Agbede}

This essay attempts to provide a better understanding of the statutory rules designed to resolve the conflict between customary and non-customary systems of laws in Nigeria. In particular it attempts to establish that under the statutory rules non-natives are amenable to customary law contrary to the view expressed in earlier cases. It also shows that the influence of customary law varies from one field of the law to another. For example, customary law is fully developed and still dominant in the fields of land transactions and family relations. It is rudimentary in the fields of tort and contract and practically silent in the fields of company law, banking, road traffic, bankruptcy, insurance, etc. and completely abolished in the field of criminal law and punishment.

The essay also shows that the choice of law rules only apply to the superior courts in which case the customary courts are not bound by them. Finally, it shows that the rules are, in the main, merely presumptions which may be rebutted in suitable cases. In short, the rules are not rigid or inflexible as the courts tend to make them.

The essay also highlights the lack of research work until lately in the area of internal conflict of laws in common law Africa generally in contrast to the intensive work done in this area by continental jurists.

\section{Religion and the State in Israel}

By ZE'EV W. FALK

The State of Israel attempts the combination of the ideas of a "Jewish state" with that of the freedoms of religion and conscience, parity of religious communities and protection of holy places. While non-Jewish communities enjoy religious 